\title{
Pemanfaatan Kulit Buah Kakao Sebagai Pakan Tambahan Pada Ternak Kambing Peranakan Etawa
}

\section{The Use of Cacao Pods as Feed Substitution for Peranakan Etawa Goats}

\author{
Yang Etika Pribadi ${ }^{1}$, Muthia Dewi ${ }^{1}$ \\ ${ }^{1}$ Program Studi Peternakan, Politeknik Pertanian Negeri Payakumbuh \\ Jl. Raya Negara Km. 7 Tanjung Pati, 26271, Payakumbuh \\ pribadiyangetika@gmail.com
}

\begin{abstract}
Diterima : 02 Desember 2018
Disetujui : 03 Desember 2018

Diterbitkan : 05 Desember 2018
\end{abstract}

\begin{abstract}
Abstrak: Percobaan ini bertujuan untuk mengevaluasi efek penambahan kulit buah kakao pada rumput lapang terhadap bobot badan kambing Peranakan Etawa (PE). Perlakuan pada penelitian disusun untuk dua ekor kambing $P E$ dengan bobot hidup awal 15 dan $18 \mathrm{~kg}$ digunakan selama 11 minggu. Perlakuan adalah $A=1,5 \mathrm{~kg}$ rumput asli dan $B=1,5 \mathrm{~kg}$ rumput asli dan 1,8 $\mathrm{kg}$ kakao. Hasil penelitian menunjukkan bahwa penambahan buah kakao dengan rumput asli mempengaruhi berat badan hidup dan efisiensi pakan kambing. Bobot badan kambing untuk perawatan A adalah 3,2 $\mathrm{kg}$ dan B 4,6 $\mathrm{kg}$. Itu menunjukkan bahwa kulit buah kakao dapat digunakan untuk menggantikan rumput asli dalam pakan kambing.
\end{abstract}

Kata Kunci : Kambing Peranakan Etawah, Kulit Buah Kakao, Pakan Tambahan.

\begin{abstract}
This experiment was aimed to evaluate the effect of addition of cocoa pod on native grass to live weight gain of goat. Two treatments were arranged for two PE goats with initial live weight 15 and $18 \mathrm{~kg}$ were used for 11 weeks. The treatments were $A=1,5 \mathrm{~kg}$ native grass and $B=1,8 \mathrm{~kg}$ cocoa pod. The results indicated thatadditon of cocoa pods with native grass influence live weight gain and diet efficiency of goats. Body weight gain of goat for treatmen A was 3,2 kg and B was 4,6 kg. Giving CBC can increase body weight gain higher goats (54.76 grams / head / day) compared with the control goats (38.10 grams / head / day). It was indicated that cocoa pod can be used to replace the native grass in sheep diet.
\end{abstract}

Keywords : Etawah Breed Goats, Cocoa Fruit Skins, Feed Supplemen.

\section{Pendahuluan}

Permintaan akan produk peternakan seperti daging kambing ikut meningkat seiring dengan peningkatan jumlah penduduk dan pendapatan masyarakat. Peternakan kambing memiliki potensi cukup baik dalam pemasarannya. Konsumen menyukai daging kambing karena rasanya yang khas sehingga banyak makanan yang terbuat dari daging kambing seperti gulai, sate, sop dan lain - lain.

Ternak kambing merupakan ternak kecil yang perawatannya mudah, cepat dikembangkan, jumlah anak perkelahiran sering lebih dari satu, jarak antar kelahiran pendek, dan pertumbuhan anaknya cepat. Salah satu jenis kambing yang digunakan sebagai penghasil daging yaitu kambing Peranakan Etawah (PE).

Kambing PE merupakan hasil persilangan kambing Etawah yaitu kambing jenis unggul dari India dengan kambing Kacang yaitu kambing asli dari Indonesia. kambing ini mudah dipelihara dan merupakan ternak penghasil daging dan juga susu. Dilihat dari ciri-ciri fisiknya kambing PE memiliki fisik lebih besar dibandingkan dengan kambing Kacang, karena produksi daging kambing PE lebih tinggi dibandingkan dengan kambing Kacang. Hal ini juga sesuai dengan harga jual kambing, harga jual kambing PE lebih tinggi dari pada kambing Kacang.

Keberhasilan dalam usaha kambing PE ditentukan dari ketersedian pakan yang berkualitas, baik itu hijauan maupun konsentrat. Pakan hijauan merupakan kebutuhan utama dalam pemeliharaan kambing, karena dari hijauan dapat terpenuhi kebutuhannya. Akan tetapi ternak kambing perlu pakan alternatif untuk menunjang produksi dan bobot hidup hidup yang optimal. Kendala dalam penyedian hijauan adalah pada saat musim kemarau akan sulit memperoleh hijauan sehingga nutrisi kambing tidak terpenuhi. Salah satu cara yang dapat dilakukan dengan pemberian kulit buah kakao (KBK) 
yang ketersediannya tinggi di perkebunan dan belum termanfaatkan.

Kulit buah kakao (KBK) merupakan hasil ikutan panenan buah kakao yang tersedia sepanjang tahun dengan produksi yang berlimpah. Buah kakao menghasilkan $74 \%$ kulit buah dan $26 \%$ isi buah yang terdiri dari biji dan musilase [1]. Kandungan gizi terdiri dari bahan kering (BK) 14,5\%, protein kasar (PK) 9,15\%, lemak 1,25\%, serat kasar (SK) 32,7 \% dan TDN 50,3\% [2]. Produktivitas kakao kering mencapai $1.382 \mathrm{~kg} / \mathrm{ha} /$ tahun, diperkirakan dapat menghasilkan KBK sebanyak 5.315,4 kg/ha/tahun. Melihat potensi produksi ikutan KBK ini maka cukup memberikan kontribusi untuk menyediakan pakan ternak ruminansia [3].

Adapun tujuan dalam melakukan penelitian adalah untuk melihat pengaruh pemberian kulit buah kakao terhadap bobot hidup Kambing PE.

\section{Materi dan Metode}

\subsection{Waktu dan tempat pelaksanaan}

Penelitian ini dilaksanakan mulai September Desember 2016. Tempat pelaksanaannya yaitu di kandang Farm Politeknik Pertanian Negeri Payakumbuh.

\subsection{Alat dan bahan}

Alat-alat yang digunakan adalah, sabit, sekop, nampan, sapu lidi, kuas, spuit. Bahan-bahan yang digunakan terdiri dari vitamin B-komplek, obat cacing, kambing PE betina, KBK dan hijauan yang berupa rumput lapang.

\subsection{Metode pelaksanaan}

Data diperoleh dari data primer dan sekunder. Data primer berdasarkan hasil pengamatan di lapangan dengan cara mengikuti secara aktif kegiatan yang berhubungan langsung dengan pemberian pakan dan pemeliharaan kambing.

\subsection{Parameter}

Parameter yang diukur adalah :

1. Konsumsi pakan;

2. Pertambahan bobot badan.

\subsection{Pelaksanaan penelitian}

Kandang yang dipakai adalah kandang kambing tipe panggung individu milik Unit Pelaksanaan Teknis (UPT) Farm Politeknik Pertanian Negeri Payakumbuh. Sebelum pemeliharaan, kandang dibersihkan dan disanitasi menggunakan kapur. Dinding, tempat pakan dan lantai kandang dibersihkan kemudian setelah kering langsung dicat dengan larutan kapur. Sekat pakan juga disiapkan yaitu dari papan untuk membatasi tempat pakan kambing kontrol dan perlakuan. Selama pemeliharaan, sekeliling kandang juga dibersihkan minimal 1 meter dari kandang untuk kebersihan lingkungan kandang.
Pengadaan kambing PE adalah jenis betina sebanyak 2 ekor dengan umur 8 bulan bobot badan 18 $\mathrm{kg}$ untuk perlakuan dan $15 \mathrm{~kg}$ untuk kontrol.

Pakan yang diberikan untuk kambing PE kontrol perlakuan yaitu rumput lapang dan perlakuan KBK pada pagi hari pukul 07.00 dan pukul 12.00 WIB diberikan rumput lapang [4]. Kambing kontrol hanya diberikan rumput lapang yaitu pada pagi hari pukul o7.0o dan sore pukul 17.00 WIB.

Tabel 1. Pemberian pakan pada ternak kambing.

\begin{tabular}{|c|c|c|c|}
\hline No & Bahan & Kontrol & Perlakuan \\
\hline 1 & Rumput Lapang & $\begin{array}{c}\text { Diberikan } \\
\text { sebanyak 1,5 kg }\end{array}$ & $\begin{array}{c}\text { Diberikan } \\
\text { sebanyak 1,5 kg }\end{array}$ \\
\hline 2 & KBK & - & $\begin{array}{c}\text { Diberikan } \\
\text { sebanyak 1,8 kg }\end{array}$ \\
\hline
\end{tabular}

Pada sistem penggemukan kambing PE ini, selain harus diperhatikan kualitas pakan hijauan yang diberikan, juga perlu dijaga kesehatan ternak dan kebersihan lingkungan kandang. Penyakit pada kambing beraneka ragam jenis dan banyak jumlahnya, seperti penyakit orf, pink eye, bloat dan diare. Upaya untuk mencegah dan mengendalikan penyakit tersebut adalah memberikan hijauan yang tidak basah, lantai kandang dibersihkan agar tetap kering. Kambing yang dipelihara diberi obat cacing (Verm O). Kambing juga diberikan B-komplek dengan cara injeksi dengan dosis 2 cc.

Penimbangan kambing dilakukan satu kali seminggu yaitu satiap hari Selasa. Tujuan dilakukan penimbangan adalah untuk melihat pertambahan bobot badan kambing serta melihat melihat bagaimana pengaruh pemberian KBK terhadap pertumbuhan kambing. Penelitian dilakukan yaitu 11 minggu. Bobot badan kambing saat awal pemeliharaan yaitu yaitu 15 dan $18 \mathrm{~kg}$.

Konsumsi pakan kambing PE yang dipelihara dapat dihitung setiap minggunya dengan cara menimbang sisa keseluruhan pakan yang diberikan mulai dari masa pemeliharaan sampai dengan akhir masa pemeliharaan, berdasarkan penjumlahan pakan harian yang diberikan dikurangi dengan pakan yang tersisa selama 24 jam.

Pertambahan bobot badan dapat dilakukan dengan cara melakukan penimbangan setiap minggunya. Bobot badan hasil penimbangan pada minggu tersebut dikurangi dengan bobot badan minggu sebelumnya.

\section{Hasil dan Pembahasan}

\subsection{Hasil}

Selama pelaksanaan penelitian dilakukan pengamatan terhadap kambing yang dipelihara, yang terdiri dari pertambahan bobot badan kambing (PBB). Hasil PBB dilihat padal Tabel 1. 
Tabel 1. Pengamatan bobot badan kambing perlakuan dan kontrol.

\begin{tabular}{|c|c|c|c|c|c|}
\hline \multirow{2}{*}{ Minggu } & \multirow{2}{*}{ Tanggal } & \multicolumn{2}{|c|}{ Bobot } & \multicolumn{2}{|c|}{ PBB } \\
\hline & & Kontrol (kg) & Perlakuan (kg) & Kontrol (kg) & Perlakuan (kg) \\
\hline o & 20-09-2016 & 15 & 18 & o & o \\
\hline 1 & $27-09-2016$ & 15,4 & 18,6 & 0,4 & 0,6 \\
\hline 2 & 04-10-2016 & 15,8 & 19,2 & 0,4 & 0,6 \\
\hline 3 & $11-10-2016$ & 16 & 19,6 & 0,2 & 0,4 \\
\hline 4 & 18-10-2016 & 16,4 & 20 & 0,4 & 0,4 \\
\hline 5 & $25-10-2016$ & 16,8 & 20 & 0,4 & o \\
\hline 6 & 01-11-2016 & 16,8 & 20,4 & o & 0,4 \\
\hline 7 & 08-11-2016 & 17 & 21 & 0,2 & 0,6 \\
\hline 8 & $15-11-2016$ & 17,2 & 21,2 & 0,2 & 0,2 \\
\hline 9 & $22-11-2016$ & 17,8 & 21,6 & 0,6 & 0,4 \\
\hline 10 & $29-11-2016$ & 18 & 22 & 0,2 & 0,4 \\
\hline 11 & o6-12-2016 & 18 & 22,4 & o & 0,4 \\
\hline 12 & $13-12-2016$ & 18,2 & 22,6 & 0,2 & 0,2 \\
\hline
\end{tabular}

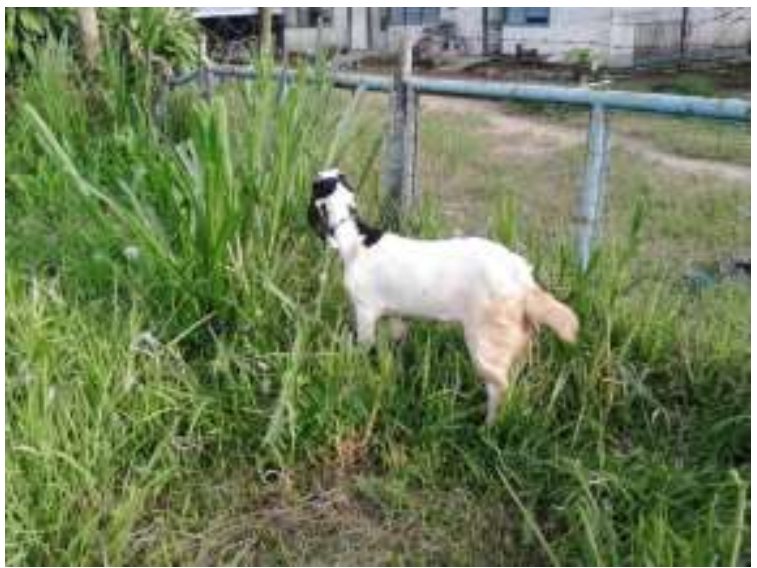

Gambar 1. Kambing PE betina

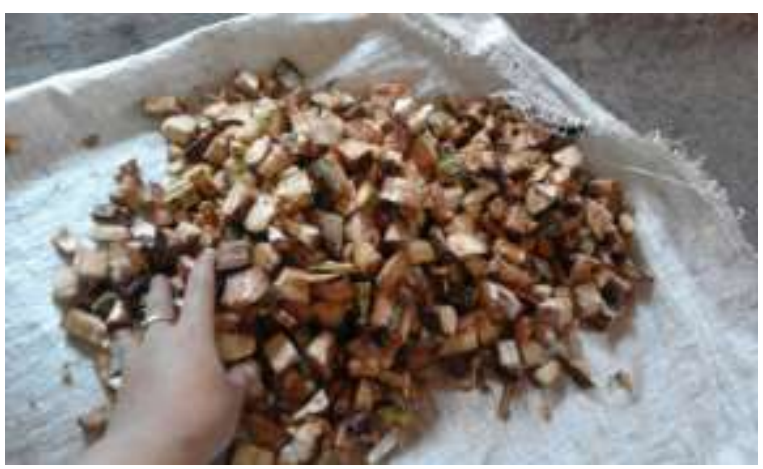

Gambar 2. Kulit buah kakao yang telah dicacah

Berdasarkan data pada hasil pengamatan, adanya pertambahan bobot badan kambing PE, PBB kambing perlakuan lebih tinggi dibandingkan dengan kambing kontrol selama 84 hari pengambilan data diperoleh total PBB sebesar 4,6 kg atau PBBH 54,76 gr. Sedangkan untuk kambing kontrol PBB yang di dapatkan lebih rendah yaitu 3,2 $\mathrm{kg}$ dengan rata-rata PBBH adalah 38,10 gr. Perbedaan PBB antara kambing perlakuan dan kontrol disebabkan oleh pemberian KBK pada kambing perlakuan. Kandungan nutrisi pakan yang didaptakan yaitu BK 6o9,9 gr, PK 46,2 gr dan TDN 313,5 gr. Dilihat dari perencanaan, PBB kambing belum mencapai $69,2 \mathrm{gr} / \mathrm{hr}$ seperti yang dilakukan oleh [4]. Penyebab tidak tercapainya PBB kambing secara optimal disebabkan karena manajemen pemeliharaan, kondisi lingkungan yang menyebabkan kambing stres.

Hasil PBB kambing perlakuan yang tertinggi pada penelitian didapat pada minggu I, II dan VII yaitu $0,6 \mathrm{~kg}$. Hal ini disebabkan kambing dalam keadaan sehat dan nafsu makan tinggi, sehingga mendukung untuk produktifitas tinggi dan bobot badan meningkat. Pada minggu VIII dan XII kambing perlakuan mengalami penurunan $\mathrm{PBB}$ yaitu $0,2 \mathrm{~kg}$ dan pada minggu $V$ pada perlakuan minggu VI dan XI tidak ada perubahan bobot badan. Hal ini disebabkan pada saat itu kambing mengalami flu yang diakibatkan perubahan cuaca dan juga mengalami stres karena kambing pindah-pindah, sehingga nafsu makan menurun dan produktifitas rendah.

Waktu kegiatan pemberian pakan tercepat menggunakan mesin adalah 41 menit dan waktu pemberian pakan terlama adalah 48 menit dengan rata-rata 44 menit yang dikerjakan oleh 1 orang pekerja. Pada kandang manual, waktu pemberian pakan tercepat adalah 111 menit dan waktu pemberian pakan terlama adalah 122 menit dengan rata-rata 117 menit yang dikerjakan oleh 3 orang tenaga kerja.

Perhitungan aspek finansial bertujuan untuk mengetahui laba rugi yang diperoleh dalam penelitian yaitu dengan menggunakan perlakuan KBK. Berdasarkan bobot badan, dapat dilihat bahwa pendapatan pada kambing perlakuan yaitu Rp. 1.849.091,- dengan $R / C_{1,13}$ sedangkan rencana yang terdapat pada perencanaan sebelumnya adalah Rp. 2.235.00o,- dengan $R / C$ 1,32. Pendapatan yang didapat lebih rendah dibanding target yang direncanakan. Pendapatan kambing kontrol yaitu Rp. 1.489.091,dengan $\mathrm{R} / \mathrm{C} \quad \mathrm{o}, 88$, sedangkan rencana pada perencanaan sebelumnya adalah Rp. 1.802.00o,- atau $\mathrm{R} / \mathrm{C}$ 1,14. Baik kambing perlakuan maupun kontrol 
sama - sama tidak tercapai sesuai dengan perencanaan hal ini disebabkan PBB pada penelitian tidak sesuai dengan perencanaan. Setelah dihitung laba rugi dengan cara menghitung selisih antara pendapatan dan biaya maka untuk kambing perlakuan yang diberi tambahan KBK mendapatkan keuntungan sebesar Rp. 209.331,- sedangkan untuk kambing kontrol mengalami kerugian sebesar Rp. 179.169,-. Dilihat dari keuntungan yang didapatkan kambing yang diberikan KBK mendapatkan keuntungan lebih besar dan layak karena nilai $\mathrm{R} / \mathrm{C}$ ratio 1,13 selama 84 hari pemeliharaan ( \pm 3 bulan).

\section{Kesimpulan}

Berdasarkan hasil pengamatan yang dilakukan maka dapat disimpulkan bahwa:

(1). Pemberian KBK dapat meningkatkan pertambahan bobot badan kambing PE lebih tinggi (54,76 gram/ekor/hari) dibandingkan dengan kambing kontrol (38,10 gram/ekor/hari).

(2). Nilai $\mathrm{R} / \mathrm{C}$ ratio dari pemeliharaan kambing yang diberi KBK adalah 1,13 sedangkan untuk kambing kontrol adalah o,88.

(3). PBB kambing belum mencapai hasil optimal sesuai perencanaan $(69,2 \mathrm{gr} / \mathrm{hari})$ karena faktor ternak dan lingkungan menyebabkan produktifitas kambing PE belum optimal

\section{Daftar Pustaka}

[1] Ginting, S.P. 2004. Tantangan dan Peluang Pemanfaatan Pakan Lokal untukPengembangan Peternakan Kambing Di Indonesia. Pros. Lokakarya Nasional KambingPotong. Kebutuhan Inovasi Teknologi Mendukung Agribisnis yang Berdayasaing.Bogor, 6 Agustus 2004. hlm. $61-78$.

[2] Balai Ternak Ciawi. 1997. Kandungan Nutrisi Kulit Buah Kakao Segar dan Kulit Buah Kakao Fermentasi.

[3] Saloko, F. 2002. Kualitas Kulit Buah Kakao Setelah Mendapatkan Larutan N-Urea 1,5\% dengan Lama Pemeraman yang Berbeda. J. Agroland. 9(1): 69-73.

[4] Munier, F.F. 2007. Seminar Nasional Teknologi Peternakan dan Veteriner. Bobot Hidup Kambing Betina Peranakan Ertawah (PE) Yang Diberikan Pakan Kulit Buah Kakao (Theobroma cacao L ). 